\title{
PEMIKIRAN ETIKA IBNU MISKAWAIH
}

\author{
Nizar $^{1}$, Barsihannor ${ }^{2}$, Muhammad Amri ${ }^{3}$ \\ ${ }^{123}$ UIN Alauddin Makassar
}

\begin{abstract}
Abstrak
Ibnu Miskawaih dijuluki sebagai bapak etika Islam. Ia telah mampu merumuskan dasar-dasar etika di dalam kitabnya Tahdzib al Akhlaq wa Thathir al A'raq (Pendidikan Budi dan Pembersihan Akhlak ). Sumber filsafat etika Ibnu Miskawaih berasal dari fisafat Yunani, peradaban Persia, ajaran syariat Islam dan pengalaman pribadi. Dalam pemikirannya mengenai etika, ia memulainya dengan menyelami jiwa manusia. Ia memandang bahwa ilmu jiwa memiliki keutamaan sendiri dibandingkan dengan ilmu-ilmu jiwa lainnya. Ajaran etika Ibnu Miskawaih berpangkal pada teori jalang tengah. Intinya menyebutkan bahwa keutamaan akhlak secara umum diartikan sebagai posisi tengah ekstrem kelebihan dan ekstrem kekurangan masing-masing jiwa manusia. Dengan demikian, menurut Ibnu Miskawaih bahwa akhlak merupakan keadaan jiwa yang mengajak sesorang untuk melakukan perbuatan tanpa dipikirkan dan diperhitungkan sebelumnya. Sehingga akhlak dapat dijadikan fitrah manusia dengan melakukan latihan-latihan yang terus menerus hingga menjadi sifat diri yang melahirkan akhlak yang baik.
\end{abstract}

Kata Kunci: Ibnu Miskawaih, Etika, akhlak.

\section{PENDAHULUAN}

Pada hakikatnya manusia itu bersifat etis, ia mempunyai potensi untuk menjadi bermoral, yaitu hidup dengan tatanan nilai dan norma. Etika merefleksikan cara manusia harus hidup, membawa diri dan menangani hidupnya secara bertanggung jawab agar berhasil sebagai manusia dan mancapai potensialitanya yang tertinggi sehingga hidupnya lebih bermutu. Dengan demikan tujuan etika tidak sekadar hanya mengetahui pandangan atau teori, ilmu, tetapi juga memengaruhi dan mendorong manusia supaya membentuk hidup suci dan menghasilkan kebaikan dan kesempurnaan serta 
memberi mamfaat kepada sesama manusia. Dengan kata lain etika mendorong kehendak agar berbuat baik. (Amin: 1993; 6-7). Etika pada dasarnya memiliki visi yang universal dan berlaku bagi segenap manusia di setiap tempat dan waktu. Namun ada kesukaran untuk merealisasikannya karena ukuran baik dan buruk menurut anggapan orang sangatlah relatif. Hal ini tentu berbeda dengan ajaran Islam dan etika Islam yang kriterianya telah ditentukan secara gamblang dalam Alquran dan hadis.

Etika merupakan hal yang sangat penting dalam kehidupan manusia. Meskipun manusia dilahirkan terpisah dari individu lain. Namun ia tidak dapat hidup sendiri terlepas dari yang lain melainkan selalu hidup bersama dalam kelompok atau masyarakat. Hal tersebut menunjukkan bahwa seseorang tidak dapat hidup sendiri tanpa bantuan orang lain, begitu pula sebaliknya. (Sumatmadja: 2005; 203-210).

Dalam sejarah filsafat Islam, upaya perumusan etika dilakukan oleh berbagai pemikir, termasuk di dalamnya ulama hukum, para teolog, mistikus dan filosof. Hal ini dikarenakan etika atau akhlak dalam Islam merupakan salah satu inti ajaran Islam. Etika dalam Islam didasarkan pada empat prinsip, yaitu pertama, Islam berpihak pada teori tentang etika yang bersifat universal dan fitri. Kedua, moralitas dalam Islam didasarkan pada keadilan. Ketiga, tindakan etis dipercaya pada puncaknya akan menghasilkan kebahagiaan bagi pelakunya. Keempat, tindakan etis bersifat rasional. (Bagir: 2005; 203). Pokok bahasan dalam tulisan ini adalah pemikiran etika Ibnu Miskawaih.

\section{PEMBAHASAN}

\section{Biografi Ibnu Miskawaih}

Nama lengkapnya adalah Abu Ali Ahmad Ibn Muhammad Ibn Ya'kub Ibn Miskawaih. (Ensiklopedia Islam: 1997; 162). Ia lahir pada tahun 320 H/932 M. di Ray dan meninggal di Isfahan pada tanggal 9 Shafar tahun 412 H/16 Pebruari 1030 M. Perihal kemajusiaannya, sebelum Islam, banyak dipersoalkan oleh pengarang Jurji Zaidan, misalnya ada pendapat bahwa ia adalah Majusi, lalu memeluk Islam. (Musa: 1963; 74). Tetapi ada juga yangberpendapat bahwa neneknyalah yang majusi, kemudian memeluk Islam. Artinya Ibnu Miskawaih sendiri lahir dalam keluarga Islam. Sebagai 
terlihat dari nama bapaknya. Muhammad. Ibnu Miskawaih hidup pada masa pemerintahan Dinasiti Buwaihi (320-450 H/932-450 M) yang sebagian besar pemukanya bermazhab Syiah.

Ibnu Miskawaih terkenal sebagai ahli sejarah dan filsafat. Di samping itu, ia juga seorang dokter, moralis, penyair, ahli bahasa serta banyak mempelajari kimia. Ia belajar sejarah, terutama Tarikh al Tabari (Sejarah yang ditulis at Tabari), pada Abu Bakar Ahmad bin Kamil al Qadi pada tahun 350 H/960M, sementara filsafat ia pelajari melalui guru yang bernama Ibnu Khamar, seorang mufasir (juru tafsir) kenamaan karya-karya Aristoteles. Abu at Tayyib ar Razi adalah gurunya di bidang kimia. Dalam bidang pekerjaan, tercatat bahwa pekerjaan utama Ibnu Miskawaih adalah bendaharawan, sekretaris, pustakawan dan pendidik anak para pemuka dinasti Buwaihi. Selain akrab dengan penguasa, ia juga banyak bergaul dengan para ilmuwan seperti Abu Hayyan at Tauhidi, Yahya Ibn Adi dan Ibnu Sina. (Tamin: 1398 H; 5).

Ibnu Miskawaih mempunyai hubungan yang baik dengan orang-orang penting dan penguasa di zamannya. Ia pernah mengabdi pada Abu Fadl al Amid sebagai pustakawannya. Setelah Abu Fadl meninggal, ia mengabdi pada putranya, Abu al Fath Ali Bin Muhammad al Amid. Kedua tokoh yang disebut terakhir adalah menteri pada masa dinasti Buwaihi. Ibnu Miskawaih mempunyai pengaruh besar di daerah Rayy. Ia mencurahkan tahun-tahun terakhir dari hidupnya untuk studi dan menulis.

Kendatipun disiplin ilmunya meliputi kedokteran, bahasa, sejarah dan filsafat, tetapi ia lebih popular sebagai filsuf akhlak ketimbang sebagai filsuf ketuhanan. Agaknya ini dimo- tivasi oleh situasi masyarakat yang kacau di masanya sebagai akibat minuman keras, perzinahan, hidup glamour, dan lain-lain. Itulah sebabnya ia tertarik untuk menitikberatkan perhatian pada bidang etika.

Ibnu Miskawaih terkenal sebagai pemikir Muslim yang produktif, ia telah menghasilkan banyak karya tulis tetapi hanya sebagian kecil yang sekarang masih ada, antara lain: al Fauz al Akbar (kemenangan besar), alFauz al Asgar(kemenangan kecil), Tajarib al Uman (pengalaman bangsa-bangsa; sebuah sejarah tentang banjir besar yang ditulis pada tahun $369 \mathrm{H} / 979 \mathrm{M}$ ), Uns al Farid (kesenangan yang tiada taranya; kumpulan anekdot, syair, peribahasa dan kata-kata mutiara), Tartib as Sa'adah (tentang ahlak dan politik), al 
Mustaufa (yang Terpilih; syair-syair pilihan), Jawidan khirad (kumpulan ungkapan bijak), al Jami' (tentang jamaah), asSiyar (tentang aturan hidup), kitab al Asyribah (tentang minuman) dan Tahzibal Akhlak (pembinaan akhlak), On the Simple Drugs (tentang Kedokteran), On the Composition of the Bajats (seni memasak), Risalah fi al Lazzah wa al Alam fi Jauhar al Nafs; Ajwibah wa As'ilah fi al Nafs wa al Aql; al Jawab fi al Masa'il al Tsalats; Risalah fi al Jawab fi Su'al Ali Ibn Muhammad Abu Hayyan al Shufi fi Haqiqahh al Aq; dan Thaharahal Nafs. (Nasution: 1999; 57).

\section{Pemikiran Etika Ibnu Miskawaih}

Bagian terpenting dari pemikiran filosof Ibnu Miskawaih ditujukan pada etika atau moral. Ia seorang moralis dalam arti sesungguhnya. Masalah moral inilah ia bicarakan dalam tiga bukunya: Tartib as Sa'ada, Tahzib al Akhlaq dan Jawidan Khirat. Dalam bidang inilah Miskawaih banyak disorot dikarenakan langkanya filosof Islam yang membahas bidang ini. Secara praktik, etika sudah berkembang di dunia Islam, terutama karena Islam sendiri sarat berisi ajaran tentang akhlak. Bahkan tujuan diutusnya Nabi Muhammad saw adalah menyempurnakan akhlak manusia. Ibnu Miskawaih mencoba menaikan taraf bagian etika dari praktis ke teoritis-fiosofis, namun ia tidak sepenuhnya meninggalkan aspek praktis.

Ibnu Miskawih dalam pemikirannya mengenai etika, ia memulainya dengan menyelami jiwa manusia. Ia memandang bahwa ilmu jiwa memiliki keutamaan sendiri dibandingkan dengan ilmu-ilmu yang lain. Manusia tidak mampu untuk meraih suatu ilmu kecuali telah mengetahui ilmu jiwa sebelumnya. Kapan seseorang memahami ilmu jiwa maka hal itu menjadi bantuan baginya untuk memperoleh ilmu yang lain. Mengetahui tentang keadaan-keadaan jiwa (ahwal an Nafs) merupakan pondasi untuk ilmuilmu yang lain seperti teologi, etika, logika. Karena mengetahui jiwa, maka seseorang memiliki senjata untuk melihat yang benar dan batil dalam masalah keyakinan dan antara kebaikan dan keburukan. (Amin: 1969; 177). Oleh karena itu, pemikiran etika Miskawaih dibangun atas pandangannya terhadap jiwa.

Ibnu Miskawaih dalam pengamatannya terhadap jiwa berkesimpulan bahwa jiwa (an nafs) bukan jism dan ardh dan bukan bagian dari jism, ia KURIOSITAS | Vol. 11, No. 1, Juni 2017 
berbeda dengan jism dan lebih mulia darinya. Jiwa adalah jauhar yang tak tertangkap oleh panca indra. Bagi Ibnu Miskawaih, jiwa tidak berubah dan hancur sebagaimana jism berubah dan hancur. Jiwa menerima semua bentuk yang pasangkan padanya, berbeda dengan jism, apabila telah mengambil sebuah bentuk maka ia tidak bisa lagi mengambil bentuk lain. Misal, apabila jism telah mengambil bentuk segitiga, maka ia tidak dapat menerima bentuk segi empat dan lainnya kecuali sebelumnya melepaskan bentuk segi tiga tersebut. (Miskawaih: 1966; 3-4). Jiwa senantiasa rindu kepada pengetahuan tentang Tuhan dan jiwa merasa bahagia dengan pengetahuan tersebut. Ini menunjukkan bahwa jiwa bukan bagian dari jism yang selalu merindukan kenikmatan materialis.

Ibnu Miskawaih membagi kekuatan (Potensi) jiwa kepada tiga tingkatan, yaitu: pertama, kekuatan berpikir (Al Quwwah an Natiqah), yaitu kekuatan untuk berpikir dan memebedakan hakikat sesuatu. Kekuatan ini dinamakan dengan al Mulkiah dan tempatnya berada di otak. Kedua, al quwwah al ghadabiah ), yaitu kekuatan untuk marah. Menolong, keberaniaan, cenderung untuk menguasai dan keinginan untuk selalu dihormati. Kekuatan ini dimakan dengan as suba'iyyah dan tempatnya berada di hati. Ketiga, kekuatan syahwatal quwwah al syahwatiyah, yaitu kekuatan syahwat yang selalu meminta makananan dan cengderungan kepada kenikmatan makanan, minuman. Kekuatan ini dinamakan dengan al bahamiyyah dan tempatnya berada di jantung (al kabid).

Ibnu Miskawaih memandang bahwa ketiga kekuatan jiwa tersebut di atas terdapat tingkatan-tingkatan. Tingkatan terendah adalah jiwa al bahimiyah, pertengahan adalah al syahwatiyah dan tertinggi adalah jiwa an nathiqah. Manusia dianggap manusia karena memiliki jiwa yang terbaik atau al nathiqah. Sehingga kemuliaan seseorang dinilai dari besar kekuatan berpikirnya. Apabila kekuatan ini dikuasai oleh kekuatan yang lain maka derajatnya pun menjadi rendah. Ibnu Miskawaih mengatakan" lihatlah di mana tempatmu. Di mana kamu suka tempat di antara tempat-tempat yang telah disediakan oleh Allah bagi makhluknya. Semua ini diberikan padamu dan kembali kepada pilihanmu, jika kamu ingin, ambillah tempat binatang, kamu akan bersamanya. Dan jika kamu ini, ambilah tempat assuba'. Jika kamu ingin, ambilah tempat para malaikat dan jadilah bagian dari mereka”. (Ibid). 
Etika menurut Ibnu Miskawaih adalahk keadaan jiwa yang melahirkan perbuatan tanpa pikiran dan perenungan. Sikap mental tersebut terbagi dua, yaitu yang berasal dari watak dan yang berasal dari kebiasaan-kebiasaan dan latihan-latihan. (al Zugby: 1995; 301). Akhlak yang berasal dari watak jarang menghasilkan akhlak yang terpuji; kebanyakan akhlak yang jelek. Sedangkan latihan dan pembiasaan lebih dapat menghasilkan akhlak yang terpuji.

Ibnu Miskawaih sangat menekankan pentingnya pendidikan untuk membentuk akhlak yang baik. Ia memberikan penting pada masa kanakkanak yang menurutnya merupakan mata rantai antara jiwa hewan dan jiwa manusia.

Etika dalam pandangan Ibnu Miskawaih dapat dikembalikan dalam dua bagian, yaitu pertama kepada tabiat atau fitrah dan kedua dengan jalan usaha (iktisab) kemudian berubah menjadi kebiasaan. Namun Ibnu Miskawaih lebih cenderung kepada yang kedua, yaitu seluruh etika semuanya adalah hasil usaha (muktasabah). Ia memandang bahwa manusia memiliki potensi untuk beretika apa saja, apakah prosesnya lambat atau cepat. Ibnu Miskawaih menetapkan kemungkinan manusia mengalami perubahan akhlak. Dari segi inilah diperlukan adanya aturan syariat, nasihat-nasihat dan berbagai macam ajaran tentang adab sopan santun.

Masalah pokok yang dibicarakan dalam kajian akhlak adalah kebaikan (al Khair), kebahagiaan (al sa'adah) dan keutamaan (al fadhilah). Kebaikan adalah suatu keadaan di mana telah sampai kepada batas akhir dan kesempurnaan wujud. Kebaikan ada dua, yaitu kebaikan umum dan kebaikan khusus. Kebaikan umum adalah adalah kebaikan bagi seluruh manusia dalam kedudukannya sebagai manusia atau dengan kata lain, ukuranukuran kebaikan yang disepakati oleh seluruh manusia. Kebaikan khusus adalah kebaikan bagi seseorang secara pribadi. (Amin: 1999; 155). Kebaikan yang kedua inilah yang disebut kebahagiaan. Dari pendapat tersebut dapat disimpulkan bahwa kebahagiaan itu berbeda-beda bagi setiap orang.

Ada dua pandangan pokok tentang kebahagiaan.Yang pertama diwakili oleh Plato yang mengatakan bahwa hanya jiwalah yang mengalami kebahagiaan. Menurutnya, selama manusia masih berhubungan dengan badan ia tidak akan memperoleh kebahagiaan. Pandangan kedua dipelopori oleh Aristoteles yang mengatakan bahwa kebahagiaan dapat dinikmati di KURIOSITAS | Vol. 11, No. 1, Juni 2017 
dunia walaupun jiwanya masih terkait dengan badan.

Ibnu Miskawaih mencoba mengompromikan kedua pandangan yang berlawanan itu. Menurutnya, karena pada diri manusia ada dua unsur, yaitu jiwa dan badan. Maka kebahagiaan meliputi keduanya. Hanya kebahagian badan lebih rendah tingkatnya dan tidak abadi sifatnya jika dibandingkan dengan kebahagiaan jiwa. Kebahagiaan yang bersifat benda mengandung kebahagiaan dan penyesalan serta menghambat perkembangan jiwanya menuju kehadirat Allah. Kebahagian jiwa merupakan kebahagiaan yang sempurna dan mampu mengantar manusia menuju berderajat malaikat.

Tentang keutamaan Ibnu Miskawaih berpendapat bahwa asas dari keutamaan adalah kecintaan manusia kepada semua manusia.Tanpa kecintaan, suatu masyarakat tidak mungkin ditegakkan. Manusia tidak dapat mencapai jati dirinya, kecuali ia hidup bersama-sama jenisnya dan saling memberikan pertolongan. Ibnu Miskawaih memandang sikap uzlah (memencilkan diri dari masyarakat) sebagai mementingkan diri sendiri. Uzlah tidak dapat mengubah masyarakat menjadi baik walaupun orang yang uzlah itu baik. Ibnu Miskawaih juga mengemukakan tentang penyakit-penyakit moral. Di antaranya adalah rasa takut dan rasa sedih, kedua penyakit itu paling baik jika diobati dengan filsafat.

Ajaran etika Ibnu Miskawaih berpangkal pada teori Jalan tengah (Nadzar Aus'at) yang dirumuskannya. Inti teori ini menyebutkan bahwa keutamaan akhlak secara umum diartikan sebagai posisi tengah ekstrem kelebihan dan ekstrem kekurangan masing-masing jiwa manusia. Posisi tengah daya bernafsu adalah iffah (menjaga kesucian diri) yang terletak antara mengumbar nafsu (al syrarah) dan mengabaikan nafsu (khumud al syahwah). Posisi tengah daya berani adalahsyajaiah (Keberanian) yang terletak antara pengecut (al jubm) dan nekad (al tahawwur).Posisi tengah daya berpikir adalah al hikma (kebijaksanaan) yang terletak antara kebodohan (al safih) dan kedunguan (al balah).Kombinasi dari tiga keutamaan membuahkan sebuah keutamaan yang berupa keadilan (al adalah). Keadilan ini merupakan posisi tengah antara berbuat aniaya dan teraniaya.

Menurut Ibnu Miskawaih, setiap keutamaan mempunyai dua eksterm. Yang tengah adalah yang terpuji dan yang ekstrem adalah tercelah.Posisi tengah di sini adalah suatu standar atau prinsip umum yang berlaku bagi 
manusia. Posisi tengah yang sebenarnya (alwasath al haqiqi) adalah satu, yaitu keutamaan (al fadilah).Yang satu ini disebut juga garis lurus (al khath al mustaqim).

Al Iffah ( menjaga kesucian diri ) adalah keutamaan jiwa al bahimiyyah. Keutamaan ini akan muncul pada manusia apabila nafsunya dikendalikan oleh pikirannya. Artinya mampu menyesuaikan pilihan yang benar sehingga bebas, tidak dikuasai dan tidak diperbudak oleh nafsunya. Sifat ini merupakan antara rakus (al syarah) dengan dingin hati (khumud al syahwat). Yang dimaksud dengan al syarah adalah tenggelam dalam kenikmatan dan melampaui batas. Sedangkan khumud al syahwat adalah tidak mau berusaha untuk memperoleh kenikmatan yang baik sebatas yang diperlukan oleh tubuh sesuai yang diizinkan syariat dan akal.

As Syaja'ah (keberanian) merupakan keutamaan dari jiwa al ghadabiyyah. Keutamaan ini muncul pada manusia sewaktu nafsunya dibimbing oleh jiwa dan nathiqah. Artinya ia tidak takut terhadap hak-hak besar jika pelaksanaanya membawa kebaikan dan mempertahankannya merupakan hal yang terpuji. Sifat ini merupakan pertengahan antara pengecut, al jubn dengan nekad, al tahawwur. Al jubn adalah takut terhadap sesuatu yang seharusnya tidak ditakuti. Sebab itu al jubn digolongkan sebagai ekstrem kekurangan. Adapun al tathawwur digolongkan berani terhadap sesuatu yang seharusnya tidak diperlukan sikap ini. Oleh sebab itu, Al tathawwur digolongkan sebagai ekstrem kelebihan.

Al hikmah (kebijaksanaan) adalah keutamaan jiwa rasional(al nafs al nathiqah) yang mengetahui segala maujud (al maujudat), baik hal-hal yang bersifat ketuhanan (al umur al ilahiyyah) maupun hal-hal yang bersifat kemanusiaan (al unsur al insaniyyah).Pengetahuan ini membuahkan pengetahuaan rasional(al maqulah) yang mampu memberi keputusan antara yang wajib yang dilaksanakan dengan yang wajib ditinggalkan. Di samping itu, Ibnu Miskawaih mengatakan kebijaksanaan adalah pertengahan (al wasath) antara kelancangan(al safh) dan kebodohan(al balah). Kelancangan yang dimaksud adalah penggunaan daya pikir yang tidak tepat. Sedangkan kebodohan adalah membekukan dan mengesampingkan daya pikir walau sebetulnya mempunyai kemampuan. Dengan demikian yang menjadi tekanan Ibnu Miskawaih di sini bukan pada sisi kualitas daya pikir, melainkan pada KURIOSITAS | Vol. 11, No. 1, Juni 2017 
sisi kemauan untuk menggunakannya.

Al adalah (keadilan) merupakan gabungan dari ketiga keutamaan al nafs. Dikatakan demikian karena seseorang tidak dapat disebut sebagai kesatria jika ia tidak adil. Demikian pula seseorang tidak dapat disebut pemberani jika tidak mengetahui keadilan jiwa atau dirinya dan mengarahkan semua indranya untuk tidak mencapai tingkat nekad (al tathawwur) maupun pengecut (al jubn). Al Hakim tidak akan memperoleh al hikmah jika ia tidak menegakkan keadilan dalam berbagai pengetahuannya dan tidak menjauhkan diri dari sifat kelancangan(al safah) kebodohan (al balah). Dengan demikian manusia tidak akan dikatakann adil jika ia tidak mengetahui cara mengharmonisasikan al hikmah, al syaja'at dan al iffah.

Menurut Ibnu Miskawaih keadilan diterjemahkan sebagai pertengahan antara al zhulm dan al Inzhilam. Al Zhulum berarti memperoleh hak milik dari sumber dan cara yang tidak semestinya (berbuat aniaya). Adapun al inzhilam adalah menyerahkan hak milik kepada yang tidak semestinya atau dengan cara yang tidak semestinya pula (teraniaya). Pengertian keadilan disini disepakati oleh para filosof bukan sebagai sebuah keutamaan tersendiri melainkan keutamaan secara menyeluruh. Keadilan ini merupakan gabungan dari semua keutamaan, karenanya ia hanya akan tercapai jika setiap jiwa mewujudkan masing-masing keutamaan. Keempat keutamaan akhlak tersebut merupakan pokok atau induk akhlak yang mulia.(Nata: 2001; 9). Akhlak-akhlak mulia lainnya seperti jujur, ikhlas, kasih sayang,hemat dan sebagainya merupakan cabang dari induk akhlak tersebut. Cabang dari keempat pokok keutamaan itu amat banyak jumlahnya, bahkan tidak terhitung.

Bedasarkan hal tersebut di atas, dapat dikatakan bahwa kontribusi pemikiran Ibnu Miskawaih dalam dunia pemikiran Islam pada khususnya dan dunia pada umumnya sangat besar peranan dan pengaruhnya.

\section{PENUTUP}

Ibnu Miskawaih terkenal sebagai ahli sejarah, filosof, dokter, moralis, penyair, ahli bahasa serta banyak mempelajari kimia. Karya-karya yang telah dihasilkan oleh miskawaih dapat dikatakan bahwa ia adalah seorang yang lihai dalam masalah etika sehingga dijuluki sebagai bapak etika Islam. Ia telah mampu merumuskan dasar-dasar etika di dalam kitabnya Tahdzib al Akhlaq 
wa Thathir al A'raq ( Pendidikan Budi dan Pembersihan Akhlak). Sementara sumber filsafat etika ibnu Miskawaih berasal dari fisafat Yunani, peradaban Persia, ajaran syariat Islam dan pengalaman pribadi.

Ibnu Miskawaih dalam pemikirannya mengenai etika, ia memulainya dengan menyelami jiwa manusia,.Iamemandang bahwa ilmu jiwa memiliki keutamaan sendiri dibandingkan dengan ilmu-ilmu jiwa lainnya. Etika menurut Ibnu Miskawaih adalah keadaan jiwa yang melakukan perbuatan tanpa pikiran dan perenungan. Sikap mental tersebut terbagi dua yaitu yang berasal dari watak dan kebiasaan serta latihan-latihan. Ajaran etika miskawaih berpangkal pada teori jalang tengah. Intinya menyebutkan bahwa keutamaan akhlak secara umum diartikan sebagai posisi tengah ekstrem kelebihan dan ekstrem kekurangan masing-masing jiwa manusia. Dengan demikian, menurut Ibnu Miskawaih bahwa akhlak merupakan keadaan jiwa yang mengajak sesorang untuk melakukan perbuatan tanpa dipikirkan dan diperhitungkan sebelumnya sehingga dapat dijadikan fitrah manusia maupun hasil dari latihan-latihan yang dilakukan hingga menjadi sifat diri yang melahirkan akhlak yang baik.

\section{DAFTAR PUSTAKA}

Amin, Ahmad.1993. Al Akhlak, Terj. Farid Ma’ruf. Etika: Ilmu Akhlak . Jakarta: Bulan Bintang. .1969. Dhuhr al- Islam, Jus II. Beirut: Dar Al Kitab Al Araby.

Bagir, Haidar.2005. Buku Saku Filsafat Islam . Bandung: Arasy..

Dewan Redaksi Ensiklopedia Islam.1997.Ensiklopedia Islam, jilid 2 . Jakarta: Ich Baru Van Hoeve

Miskawaih, Ibnu. 1966. Tandzib al Akhlaq . Beirut: American Univ. Press.

Nasution, Hasyimsyah. 1999 Filsafat Islam. Jakarta: Gaya Media Pratama.

Nata, H. Abuddin. 2001 Pemikiran para Tokoh Pendidikan Islam, ed. 1. Jakarta: RajaGrafindo Persada.

Sumatmadja, H. Nursid. 2005.Manusia dalam konteks Sosial, Budaya dan Lingkungan Hidup .Bandung: Arasy.

Tamin, Hasan. "al Muqaddimah" dalam Tahzib al Akhlaq wa Tathbir al A'raq. Beirut: Mansyurat.Dar al Hayat, 1398 H.

KURIOSITAS | Vol. 11, No. 1, Juni 2017 
Musa, Muhammad Yusuf. 1963. Falsafah al Akhlak fi al Islam.Kairo: Muassat al Khaniji.

al Zugby, Fathi Muhammad. 1995. Falsafah al Akhlaq 'Inda Maskawaih, Juz II. Tanta, Mesir: Maktabah Asywal. 